\title{
What Does the Girls Say in Social Media (A Study of Self-Disclosure on Instagram @ RahasiaGadis)
}

\author{
Chrisantya Tamara Evani Arthadea ${ }^{1}$ Nigar Pandrianto $^{1 *}$ \\ ${ }^{1}$ Faculty of Communication Science, Universitas Tarumanagara, West Jakarta 11440, Indonesia \\ ${ }^{*}$ Corresponding author. Email: nigarp@ fikom.untar.ac.id
}

\begin{abstract}
The development of information and communication technology has resulted in a different pattern of life for society. Advances and developments in technology encourage communication patterns to develop in a digital direction. One of the digital media that is developing in society is Instagram. In communicating, individuals need self-recognition and self-disclosure of information about themselves to their interlocutors. The context of self-disclosure on social media generally lies in how individuals share information about themselves in the form of photos / videos, status, comments, and chat. This research uses descriptive qualitative research methods through case studies by collecting data in the form of interviews, documentation, and literature study. The results of this study state that self-disclosure on social media can help some individuals to solve problems and get new points of view and have an opinion on the same experiences or events. However, individuals feel that they will not reveal themselves on social media if there is no topic first and are considered less effective.
\end{abstract}

\section{Keywords: Digital communication, new media development, self-disclosure}

\section{INTRODUCTION}

The use of social media is increasingly widespread. The number of users is increasing all the time. This shows that the dependence on social media is getting higher. This happens because of the widespread use of digital devices, especially the use of smartphones. We Are Social reported that the increase in the number of social media users between 2019 and 2020 reached $9.2 \%$. This number will increase significantly from year to year. This happens because of the easier and cheaper internet access. Given the growing number of social media users, a question can be asked, what are they really looking for on social media. There are many motivations that underlie someone having a social media account, one of which is to build relationships with other humans [1]. As in real life, humans who are on social media also have a need to explore relationships with other humans [2]. Not only building relationships, they can also do other things such as various information [3], [4], and to collaborate with other followers. This is what is then used by big companies or brands to communicate with them [3], [5]. Talking about social media users, we know that each social media platform has its own advantages. Tik Tok, for example, is based on short video content, Whatsaspp with an instant messenger platform, Youtube which is based on videos with a longer duration and Instagram which is based on photos or graphic content. In early 2020, Instagram was mentioned by We Are Social as the sixth most widely used social media platform. That is why research on Instagram is very interesting to do. One point that can be researched from Instagram or other social media is a portrait of the use of social media by its users. From here we can find the characteristics of the use of social media [6], [7]. Usage characters will show ways of thinking, patterns of interaction, behavior, motivation [8], reasons for having social media accounts, to their political participation [9], [10]. This of course will be very useful for other scientific fields.

Communication between communities, which was initially carried out orally or verbally as a form of message exchange, has become digital communication. Individuals need selfdisclosure as a form of need in terms. According to Gillin and Gillin in Soekanto (1982), social and dynamic relationships between humans are the definition of social interaction [11]. In social interaction, an individual tends to reveal himself and convey information about himself. Self-disclosure contains a variety of information ranging from surface to intimate information [12]. This self-disclosure can occur between people who do not know each other and people who have a close relationship. Information conveyed in self-disclosure can be descriptive or evaluative, and can include a person's thoughts, feelings, fears, dreams, likes and dislikes. Selfdisclosure through social media can be in the form of status, videos, photos, comments, direct messages, chat, and others. People who dare to express themselves through other people who don't believe, but there are some individuals who share their opinions on social media. Expressing oneself on social media means publishing information about themselves in social media, this cannot be done directly [13].

Instagram account RahasiaGadis which is categorized as Health and Beauty has more than 3 million followers. RahasiaGadis is an Instagram social media account that has varied and useful content for its followers, especially female 
teenagers. This content includes, motivation, tips, quotes and confession room. RahasiaGadis become a platform for the community, especially followers, to voice and speak up about the problems. Followers of RahasiaGadis are $83 \%$ dominated by women and $17 \%$ of men with an age range of $18-24$ years of $51 \%$, then $25-34$ years of $33 \%$ and the rest divided into several age ranges. RahasiaGadis followers are spread throughout Indonesia and mostly in big cities, such as Jakarta with a total of $20.59 \%$ (source: RahasiaGadis).

This paper specifically wants to provide an overview of how self-disclosure is to Instagram social media users @ RahasiaGadis. Self-disclosure is considered important because it shows the extent to which an account owner reaches a high enough level to communicate openly with other people.

\subsection{Related Work}

\subsubsection{Youth and self-disclosure in social media}

The 15-26 year age group is the group with a large number of social media users. They use various social media platforms for various purposes [6], such as exchanging content, ranking content to organizing flash mobs [8] [14]. This makes social media feel like real life. Humans who interact with other humans through social media can have very close, deep, and mutually open relationships. Even in human history, a high level of interconnectivity is when humans build relationships through social media [15]. This is not surprising because basically humans will choose media that can meet their needs (human social beings). So that when there is a media with characters that can meet the need for interaction, they will immediately accept it. In addition, the use of social media is also intended to form a positive image and identity [6].

However, strong interactions with other humans through social media are determined by several things, one of which is self-disclosure [16]. Self-disclosure is an ability of someone to give personal informations to others about things that are not easily known by others. This information can be superficial, to intimate or closer information. The factors that influence self-disclosure are individual differences, relationships, culture, gender, and communicants [14][17]. Etymologically, self-disclosure comes from English, "self" means oneself, and "disclosure" from the word "closure" which can be interpreted as determination, ending, so that "disclosure" means openness. Self-disclosure is selfdisclosure. Self-disclosure is the desire of individuals to voluntarily disclose personal information about themselves to others in order to develop intimacy towards their opponent's interaction [18]. According to Devito, self-disclosure is information about oneself, about someone's thoughts, feelings and behavior, or about other people that is conveyed to others. This is a form of interpersonal communication [19].

Interestingly, this self-disclosure is reciprocal. This does not only happen to offline relationships, but also to relationships through social media. The more someone opens up to other people, the more people will open up to others. The higher the self-disclosure, the higher the closeness that occurs in a relationship [16]. In essence, self-disclosure is the basis of a good relationship. Even this self-disclosure in a different cultural environment can not only build friendly relations, but also romance, sexual attraction, consultation on certain issues. This happened without them ever meeting [20]. This is an example of how social media is able to create new realities that humans have never imagined before.

But there is a possibility that there will be differences in someone's behavior when they are online, or when they make relationships offline. The causes include dissociative anonymity, invisibility, asynchronicity, solipsistic interjection, dissociative imagination, and dissociative imagination [21]. Here anonymity makes a significant contribution. They prefer to hide their identity so feel free to give comments, or express their opinions on social media [21]. Moreover, social media account owners use social media to reveal personal issues. Thus, anonymity has two different perspectives [22]. On the one hand, it has positive values, namely encouraging freedom to express oneself, gain support, and even build a community that can provide solutions to certain problems. But besides that it has a negative side, namely the possibility of misusing the account for harmful and detrimental purposes such as cyberbullying, trolling and deception [23].

Therefore, those who are not ready for all the consequences of interacting through social media, have to rethink whether they really chose the right choice or not. Especially for teenagers. There are several factors that cause them to want to interact through social media. First is because they want to get attention, ask for opinions or suggestions from other social media users, and improve their image [24]. In fact, there are also those who argue that adolescent social media users are closely related to levels of loneliness and a sense of belonging [8].

From the research conducted, there are several psychosocial factors that are considered to determine the occurrence of good relationships. These factors are comfort, personality, intimacy, reciprocity, anonymity and gender [20]. Research conducted in South Africa shows that gender stereotypes are still very influential. There are those who feel more comfortable discussing with other genders, but there are also those who feel uncomfortable communicating with different genders. This means gender type self-disclosure. Concretely, for example, women actually prefer to do self-disclosure with women, than with men [20].

Therefore, this paper can reveal more deeply about selfdisclosure in social media where social media followers are dominated by women. With a different method, it is hoped that the research results in this paper can provide a deeper picture of the relationships and patterns of women's selfdisclosure on social media.

This is important because by understanding the characteristics of their followers, it will be easier for social media account managers to process messages so that the goals of a social media account can be achieved.

\subsection{Our Contribution}

The purpose of this research is to see self-disclosure in Instagram social media. The results of this study are expected 
to be useful as reference material and reference in further research for readers who will discuss similar topics but from different points of view. The results of this study are expected to develop communication science, especially communication psychology related to self-disclosure. The results of this study are expected to educate the public about self-disclosure in social media Instagram and are expected to increase researchers' insights regarding self-disclosure on Instagram social media.

\subsection{Paper Structure}

The Paper is structured in 5 sections as follows: section 1 is an introduction to the problems in research. Section 2 author describe the theory used in the research. Section 3 is an explanation of the methods the research uses in determining, collecting, and processing research data. Section 4 is the findings and discussion based on processed data and is linked to the theory used in the research. In section 5 the author draws and overall conclusion regarding the research carried out then followed by an acknowledgment of the authors origin of institution. Last, was references included in the paper.

\section{BACKGROUND}

\subsection{Digital Communication}

Humans are said to be social creatures, which means that humans cannot live alone and depend on one another. Communication is an important element in human life. Etymologically, the term or word of communication (from English "communication") comes from Latin which means communicatos and comes from the word communis. Communist means "sharing" or "belonging together", which is an effort that has the goal of togetherness or common meaning. Digital communication utilizes digital technology to send messages such as email, video, search engines, press releases, online advertisements, podcasts, social media, and others.

Definition 1. (Communication) According to Harold D. Laswell, communication is a good way to describe communication by answering the following questions "Who says what and with channels to whom with what effect?" or who said what with what channel to whom with how influence [25].

\subsection{Social Media}

The development of the digital era has produced to various new social media, including Instagram, Facebook, Whatsapp, Twitter, and many more. According to Nasrulah in the book Social Media; Communication, Culture, and Sociotechnology Perspectives (2015), social media is an internet medium that allows individuals to present themselves, interact, cooperate, share and communicate with other users and form social bonds virtually. In social media, three forms that refer to the meaning of being social are cognition, communication and cooperation [26].
Definition 1. (Social Media) According to Taprial and Kanwar (2012), social media is the media used by individuals to become social online, by sharing content, news, photos and others [27].

\subsection{New Media}

The development of new media (New Media) includes the emergence of digital, computer, or information and communication technology networks. According to McQuail, New media is multi-directional, has no audience so that there is no mass public, is very diverse in the form of its content, and there are no boundaries between private and public space [28].

Instagram is one of the social media that is growing in society. Over time, the use of Instagram is not only limited to uploading photos or videos. Instagram can be used as a platform for doing business, looking for information, entertainment and a place to vent. The increasing number of Instagram users encourages humans to continue to develop and adapt to technology. The Instagram account as a place to "vent" is one example. Networking between users is a basic character of social media. This network serves to expand relationships between users on the internet and is built through interactions on Instagram. The form of interaction that can be done through Instagram is by providing a "like" button on other users' uploads, commenting on other users' uploads, replying to other users' Instagram stories, or simply exchanging messages via direct message.

\subsection{Self-disclosure}

Self-disclosure is the desire of individuals to voluntarily disclose personal information about themselves to others in order to develop intimacy towards their interaction opponents [18].

According to Devito (2011), self-disclosure in the form of information about oneself about one's feelings, thoughts, behavior, and experiences that have been experienced by oneself [14]. Self-disclosure as expressed by Devito occurs because of openness. This openness can occur because individuals need a place to pour out their hearts and feelings in order to be heard, understood, understood, and responded to by other individuals. Self-disclosure occurs not only in direct communication and interaction, but can occur through the media, namely social media. Self-disclosure can be done through various media, one of which is social media. The context of self-disclosure on social media generally lies in how individuals share information about themselves in the form of photos / videos, status, comments, chatting, and so on.

\section{METHODS}

This study uses a qualitative descriptive research approach with a case study method that is intended to determine selfdisclosure in social media Instagram, According to Kriyantono, a qualitative approach is a technique that describes and interprets the meaning of data that has been 
collected by paying attention and recording as many aspects of the situation under study at that time, so as to obtain a general and comprehensive picture of the actual situation [29]. Especially in the comment column of RahasiaGadis content. In addition to the subject and object of research, the subject of this study is a digital communication expert, psychologist and RahasiaGadis Instagram followers. Meanwhile, the object of this research is Self-disclosure in Instagram Social Media (Case Study on RahasiaGadis Followers). A case study is a series of scientific activities carried out intensively, in detail, and in depth about a program, event and activity, whether at the level of an individual, group of people, institution or organization to obtain in-depth knowledge of the event. Usually, the selected events, which are hereinafter referred to as cases, are real-life events, which are ongoing, not something that has passed.

The data collection method that the writer uses is primary and secondary, namely by conducting interviews with sources, namely Dr. Firman Kurniawan as Digital Communication Expert, Mayasari Sulistyandari S.Psi., M.Psi as Psychologist, and Cyntia Enggelina, Inggrit Laurenza, and Marshanda Anissa as RahasiaGadis followers. The data collection

\section{FINDINGS AND DISCUSSIONS}

\subsection{Digital Communications on RahasiaGadis Accounts}

According to Harold D. Laswell, a good way to describe communication is to answer the following questions "Who says what and with channel to whom with what effect?" or who said what by what channel to whom with how influence [25]. The development of digital technology, supported by the advancement of the internet, has brought tremendous impacts and changes and has enabled changes in communication media. Communication media is a tool used to communicate, digital media is a tool used to communicate via the internet. In this case, advances and developments in technology encourage communication patterns to develop in a digital direction. This results in changes to individual behavior, especially in terms of communication. The evolution of web 1.0 which is only able to load content in one direction. In the era of the web $1.0 \mathrm{blog}$, there has been a change in the behavior of individuals who treat information from being private to being uploaded to the public domain. In the development of web 2.0, the development of digital media communication has become interactive, individuals can comment on each other from all directions. From here, groups of haters and lovers emerged. Digital medium provides a place for all kinds of content which are text, audio, visual, and convergent text. In the midst of the development of the digital medium as a communication medium, what needs to be considered is the content or message that will be conveyed to the audience.

Digital communication in the use of social media lies in the content of RahasiaGadis Instagram. RahasiaGadis can be an alternative for individuals to train and read about selfdevelopment or self-improvement in the form of new method is then the researcher uses the documentation method as a form of attachment or supporting data, and uses a literature study using a variety of information in the form of books, journals, and other references as a form of support for this research.

Researchers will perform data collection techniques by determining key informants based on the suitability of the topic being studied. The informants of this study are psychologists, social media experts, and several followers. Furthermore, the researcher will carry out data collection methods (interviews, documentation, and literature study) and select and select data to be attached as supporting data in the research. So that researchers will be able to carry out analysis and then draw conclusions. In this study, researchers used data source triangulation, which means that researchers will seek the truth of data from different sources. Researchers will use interview sources, documentation, data archives and literature study. Furthermore, the data that researchers obtain will be analyzed by researchers and researchers will provide different insights about the phenomenon under study. These various views will create a breadth of knowledge to obtain the truth.

media, namely digital media. RahasiaGadis also provides motivation to several individuals, such as providing content in the form of a confession room which functions as a media to confide in for teenagers. With the presence of confession room content, media users are willing to open up about the problems they are experiencing. At least other individuals know the stories of confession room content users even though they are through digital or online media. Digital communication carried out by RahasiaGadis lies in the interactive patterns and interactions between followers that are carried out through the comments column. RahasiaGadis also provides interesting and interactive content to increase interest in Instagram accounts.

\subsection{New Media Development}

The development process of digital communication through digital communication media produced to new media in society. According to McQuail, New media has very diverse content, there is no boundary between privacy and the public and has no audience or public and mass (multidirection) [28]. New media is a description of the characteristics of different media. Media such as television, radio, newspapers and magazines are classified as old media, while media that uses internet networks such as social media are classified as new media.[30].

The presence of new media is one thing that is very striking for individual behavior patterns, what used to be done with direct contact with other individuals, so now it is enough to use digital devices in the form of social media or applications. According to Dr. Firman Kurniawan, The development of communication technology has become a new euphoria marked by the ease in obtaining information and the ease in communicating. The development of new media resulted in a big leap marked by the absence of boundaries between private and public spaces. 
The development of new media also helps people to find information quickly and easily communicate without distance and time restrictions. New media allows individuals to increase the reach of their friends, and can even become a means of buying and selling online shops. Interactions carried out either directly or through media intermediaries such as digital communication media produce symbolic interaction theory. The purpose of symbolic activities is to form meaning and in symbolic interactions there are objectives to be achieved. Symbolic interactions through digital communication media are used by individuals as a place to get their goals and open themselves or express themselves. In this case, the development of social media is very helpful for some individuals who really need self-disclosure, but are ashamed and feel embarrassed to express themselves directly.

\subsection{Self-disclosure in Instagram}

Etymologically, self-disclosure comes from English, "self" means self, and "disclosure" from the word "closure" can be interpreted as closing, ending, so that "disclosure" means openness. Self-disclosure is the disclosure of information about oneself about one's feelings, thoughts, behavior, and experiences that have been experienced [14]. Selfdisclosure is a form of interpersonal communication in the form of sharing personal information in the form of ideas, feelings and fantasies and expressing reactions and responses to situations that are generally hidden but conveyed so that other people know what is being thought, felt and wanted.

This openness can occur because individuals need a place to pour out their hearts and feelings in order to be heard, understood, and responded to by other individuals. Selfdisclosure occurs not only in direct communication and interaction, but can occur through the media, namely social media. The context of self-disclosure in Instagram is a form of deliberate purpose and purpose, such as easing the burden on the mind, getting responses from other users, and just pouring out one's heart and mind.

According to psychologist Mayasari Sulistyandari S.Psi., M.Psi, self-disclosure is important and very necessary for each individual. Self-disclosure allows individuals to exchange ideas with other individuals with the aim of solving problems faced and receiving input from other individuals. Self-disclosure is usually done by adolescents

other individuals who are uploaded by RahasiaGadis. From these uploads, the three followers dared to comment if they felt they had the same story or experience because they thought that they did not experience the experience themselves.

Based on the researchers' observations, the content of the confession room in RahasiaGadis Instagram with the topic that received the most comments was the problem of female adolescent problems. Examples are relationships with other individuals (love, friendship), sexual harassment, insecure (weight, skin color, beauty), and family problems (parents, siblings, or younger siblings). because of the need to relieve tension, anxiety, besides feeling that they have friends to express their experiences. The main factor that encourages individuals to perform selfdisclosure is the feeling of having the same experience with other individuals.

Based on the results of interviews with RahasiaGadis followers, they all revealed that they would not start disclosing themselves first and chose to remain silent if RahasiaGadiss did not upload about other individual selfdisclosures first. Self-disclosure in the content of the RahasiaGadis Account is in the form of comment on comment, which means that self-disclosure occurs due to comments from other individuals first. Self-disclosure on social media is considered not to have a significant impact, because when self-disclosing on social media, individuals do not really know that their story is being heard or are just curious. In contrast to direct self-disclosure, individuals who express themselves can know and feel sympathy and empathy from other individuals. Added by Dr. Firman Kurniawan, social media provides anonymous facilities, which means that not all self-disclosures on social media are genuine identities.

The positive impact that is felt when expressing yourself on Instagram includes feeling supported, feeling relieved, and the problem at hand is resolved from the point of view of another individual. Self-disclosure on social media is encouraged because individuals feel that they have had the same experiences or events as other individuals, so there are opportunities to share experiences and similar incidents in the context of self-disclosure. However, there is a negative impact that is felt when expressing yourself on Instagram, including feelings of discomfort, the information being disseminated cannot be contained.

Based on the results of interviews by RahasiaGadis followers, namely Cyntia Enggelina, Inggrit Laurenza, and Marshanda Anissa, it is revealed that the most important reason for self-disclosure is having the same experience as other individuals who tell stories. Self-disclosure also makes individuals feel able to help other individuals who are having problems and express themselves on social media. By commenting, individuals feel they can ease the burdens and problems of other individuals who reveal themselves. Individu get responses or feedback from other individuals when they started to self-disclosure in social media. They all started self-disclosure through "comment on comment" in the RahasiaGadis Instagram feed. The reason they dare to speak is because there is already a place or place and it is started by the outpouring of the hearts of

\section{CONCLUSIONS}

The development of digital communication is a big leap, and the presence of new media is very striking for individual behavior patterns. Digital communication has produced to social media or new media as a medium of communication. The presence of new media as a communication medium provides changes to individual interaction patterns in terms of communication. In communicating, individuals need self-recognition and self-disclosure of information about 
themselves to their interlocutors. The context of selfdisclosure on social media generally lies in how individuals share information about themselves in the form of photos / videos, status, comments, chatting, and so on. Selfdisclosure in the context of commenting on the selfdisclosure of other individuals is classified as not having a significant impact and the source will not begin to reveal themselves through the RahasiaGadis Instagram social media account. However, the positive side is that individuals get a new perspective on a problem at hand and individuals feel supported by the support of other individual comments.

\section{ACKNOWLEDGMENT}

This work was supported by Faculty of Communication University Tarumanagara, Jakarta 11440, Indonesia, and International Conference of Economics, Business, Social, and Humanities (ICEBSH) 2021.

\section{REFERENCES}

[1] P. B. Brandtzæg and J. Heim, "Why people use social networking sites," Lect. Notes Comput. Sci. (including Subser. Lect. Notes Artif. Intell. Lect. Notes Bioinformatics), vol. 5621 LNCS, no. June, pp. 143-152, 2009, doi: 10.1007/978-3-642-02774-1_16.

[2] C. Montag and S. Diefenbach, "Towards homo digitalis: Important research issues for psychology and the neurosciences at the dawn of the Internet of Things and the digital society," Sustain., vol. 10, no. 2, 2018, doi: 10.3390/su10020415.

[3] C. Du Plessis, "The role of content marketing in social media content communities," SA J. Inf. Manag., vol. 19, no. 1, pp. 1-7, 2017, doi: 10.4102/sajim. v19i1.866.

[4] A. Y. Yaqubi and I. Karaduman, "The Impact of Content Marketing on Consumers' Purchase Intention for Home Appliances : A Study in Afghanistan," Int. J. Bus. Manag. Invent., vol. 8, no. 02, pp. 38-47, 2019, [Online]. Available: http://www.ijbmi.org/papers/ Vol(8)2/Series. 3/G0802033847.pdf.

[5] J. Rowley, "Understanding digital content marketing," J. Mark. Manag., vol. 24, no. 5-6, pp. 517540, 2008, doi: 10.1362/026725708X325977.

[6] T. R. Afriluyanto, "Fenomena Remaja Menggunakan Media Sosial dalam Membentuk Identitas,"
KOMUNIKA J. Dakwah dan Komun., vol. 11, no. 2, pp. 184-197, 2018, doi: 10.24090/komunika.v11i2.1365

[7] M. Cross, "What is Social Media?," Soc. Media Secur., pp. 1-20, 2014, doi: 10.1016/b978-1-59749-9866.00001-1.

[8] H. Seo, J. B. Houston, L. A. T. Knight, E. J. Kennedy, and A. B. Inglish, "Teens' social media use and collective action," New Media Soc., vol. 16, no. 6, pp. 883-902, 2014, doi: 10.1177/1461444813495162.

[9] D. Rahmawati, "Media Sosial Dan Demokrasi Di Era Informasi," J. Vokasi Indones., vol. 2, no. 2, pp. 3-4, 2016, doi: 10.7454/jvi.v2i2.40.

[10] W. R. Jati, "Cyberspace, Internet, Dan Ruang Publik Baru: Aktivisme Online Politik Kelas Menengah Indonesia," J. Pemikir. Sosiol., vol. 3, no. 1, p. 25, 2016, doi: 10.22146/jps.v3i1.23524.

[11] S. N. Istiqomah, "Pengaruh kematangan emosi dan kecerdasan sosial terhadap interaksi sosial siswa program akselerasi," vol. 53, no. 9, p. 287, 2015.

[12] R. Loisa and Y. Setyanto, "Penyingkapan Diri Melalui Internet Di Kalangan Remaja (Studi Komunikasi Antar Pribadi)," J. Komun. Untar, vol. 6, no. 3, pp. 31-43, 2014.

[13] W. Ningsih, "Self-disclosure Pada Media Sosial ( Studi Deskriptif Pada Media Sosial Anonim LegaTalk )," Skripsi Progr. Stud. Komun. Fak. Ilmu Sos. dan Ilmu Polit. Univ. Sultas Ageng Tirtayasa, 2015.

[14] A. Sagiyanto and N. Ardiyanti, "SELFDISCLOSURE MELALUI MEDIA SOSIAL INSTAGRAM (Studi Kasus Pada Anggota Galeri Quote)," Nyimak (Journal Commun., vol. 2, no. 1, pp. 81-94, 2018, doi: 10.31000/nyimak.v2i1.687.

[15] S. P. Christensen, "Social media use and its impact on relationships and emotions," All Theses Diss., pp. 173, 2018, [Online]. Available: https://scholarsarchive. byu.edu/etd/6927.

[16] A. C. Orben and R. I. M. Dunbar, "Social media and relationship development: The effect of valence and intimacy of posts," Comput. Human Behav., vol. 73, pp. 489-498, 2017, doi: 10.1016/j.chb.2017.04.006.

[17] V. I. Sinta Paramita, Riris Loisa, Yugih Setyanto, "Filter Gelembung, Ruang Bergema, dan Personaliasi Algoritma," Buku Literasi, no. August, pp. 189-199, 2019. 
[18] S. M. Karina and Suryanto, "Pengaruh Keterbukaan Diri terhadap Penerimaan Sosial pada Anggota Komunitas Backpacker Indonesia Regional Surabaya dengan Kepercayaan terhadap Dunia Maya sebagai Intervening Variabel," J. Psikol. Kepribadian dan Sos., vol. 1, no. 02, pp. 115-121, 2012.

[19] G. J. Setiadi, "Self-disclosure individu androgini melalui instagram sebagai media eksistensi diri," J. Stud. Komun. (Indonesian J. Commun. Stud., vol. 3, no. 2, p. 272, 2019, doi: 10.25139/jsk.v3i2.1497.

[20] M. A. Edwards, J. G. Howcroft, and T. Lambert, "Young Adults " Perceptions of Online Self Disclosure," vol. 13, no. 1, pp. 26-42, 2021, doi: 10.5539/res.v13n1p26.

[21] P. S. Perbawani, R. Rahayu, and I. N. Anshari, "Netizens Anonymity in Indonesia's Digital Democracy: Political Participation in Social Media According to the Online Disinhibition Effect Theory," PCD J., vol. 6, no. 2, p. 185, 2018, doi: 10.22146/pcd.41905.

[22] J. Hancock, "Anonymity-Intimacy-Disclosure," 2016.

[23] N. Andalibi, O. L. Haimson, M. De Choudhury, and A. Forte, "Social support, reciprocity, and anonymity in responses to sexual abuse disclosures on social media," ACM Trans. Comput. Interact., vol. 25, no. 5, 2018, doi: $10.1145 / 3234942$.

[24] P. Felita, C. Siahaja, V. Wijaya, G. Melisa, M. Chandra, and R. Dahesihsari, "Pemakaian Media Sosial Dan Self Concept Pada Remaja," J. Ilm. Psikol., vol. 5, no. 1, pp. 30-41, 2016.

[25] S. Wu, J. M. Hofman, W. A. Mason, and D. J. Watts, "Who says what to whom on twitter," Proc. 20th Int. Conf. World Wide Web, WWW 2011, pp. 705-714, 2011, doi: 10.1145/1963405.1963504.

[26] A. Setiadi, "Pemanfaatan media sosial untuk efektifitas komunikasi," J. Hum., vol. 16, no. 2, pp. 1-7, 2016, [Online]. Available: https://ejournal.bsi.ac.id/ ejurnal/index.php/cakrawala/article/download/1283/105 5.

[27] D. R. Rahadi, "Perilaku Pengguna Dan Informasi Hoax Di Media Sosial," J. Manaj. Dan Kewirausahaan, vol. 5, no. 1, pp. 58-70, 2017, doi: 10.26905/jmdk. v5i1.1342.

[28] B. Bayquni and A. A. Saputra, "Kebijakan Redaksi Media Sosial Partai Demokrasi Indonesia Perjuangan Jakarta Timur Dalam Menentukan Pemberitaan," $J$. Pustaka Komun., pp. 131-142, 2019, [Online].
Available: http://journal.moestopo.ac.id/index.php/ pustakom/article/view/884.

[29] K. A. Akhmad, "Pemanfaatan Media Sosial bagi Pengembangan Pemasaran UMKM (Studi Deskriptif Kualitatif pada Distro di Kota Surakarta)," Duta.com, vol. 9, no. September, pp. 43-54, 2015, [Online]. Available: http://journal.stmikdb.ac.id/index.php/ dutacom/article/view/17.

[30] E. D. S. Watie, "Komunikasi dan Media Sosial (Communications and Social Media)," J. Messenger, vol. 3, no. 2, p. 69, 2016, doi: 10.26623/themessenger. v3i2.270. 